\title{
Malnutrition Prevention
}

\author{
Patrick Roigk and Fabian Graeb
}

\begin{abstract}
A healthy nutritional intake is required to prevent malnutrition. Furthermore, nutrition is associated with improved quality of life in older adults. Simultaneously, many factors influence nutritional intake in later life. Onset and progression of acute or chronic diseases and a reduced dietary intake play a crucial role in developing malnutrition. Malnutrition is associated with poor outcomes such as pressure injury, increased length of hospital stays and increased mortality. The aim of the chapter is to increase the nutritional-based knowledge of the interdisciplinary team to prevent malnutrition in all its forms. Therefore, this chapter offers evidence-based information to support interdisciplinary prevention of malnutrition in older adults across diverse healthcare settings.
\end{abstract}

\section{Keywords}

Malnutrition prevention - Risk factors · Nutritional care · Prevention · Public health $\cdot$ Malnutrition

This chapter is a component of Section 1: Nutritional Care in Old Age.

For an explanation of the grouping of chapters in this book, please see Chap. 1: 'Overview of Nutrition Care in Geriatrics and Orthogeriatrics'.

\footnotetext{
P. Roigk $(\triangle)$

Department of Clinical Gerontology and Geriatric Rehabilitation, Robert-Bosch-Hospital, Stuttgart, Germany

e-mail: Patrick.roigk@ rbk.de; https://www.rbk.de

F. Graeb

Faculty Social Work, Education and Nursing Science, Hochschule Esslingen - University of Applied Sciences, Esslingen, Germany

e-mail: fabian.graeb@hs-esslingen.de; https://www.hs-esslingen.de
}

Ó. G. Geirsdóttir, J. J. Bell (eds.), Interdisciplinary Nutritional Management and

Care for Older Adults, Perspectives in Nursing Management and Care for Older

Adults, https://doi.org/10.1007/978-3-030-63892-4_4 


\section{Learning Outcomes}

By the end of this chapter, you will be able to:

- Know your role within the process of preventing malnutrition.

- Demonstrate awareness of the nutritional needs of older adults.

- Identify older adults at risk of malnutrition.

- Understand and apply opportunities to prevent malnutrition.

\subsection{Malnutrition and Its Risk Factors}

Enjoying a wide variety of nutritious foods supports older adults to stay healthy and feel well. Insufficient nutrition leads to a loss of health-related resources, particularly in older age. Although definitions vary globally, according to the recent ESPEN consensus and terminology of clinical nutrition [1,2], malnutrition is defined as:

- A serious reduced body mass (i.e. BMI $<18.5 \mathrm{~kg} / \mathrm{m}^{2}$ ) or

- An unintended weight loss ( $>5 \%$ in 6 months or $>10 \%$ beyond 6 months) and either

- A BMI $<20 \mathrm{~kg} / \mathrm{m}^{2}$ ( $<70$ years)/a BMI $22<\mathrm{kg} / \mathrm{m}^{2}$ ( $\geq 70$ years) or serious reduced muscle mass (i.e. FFMI $<15 \mathrm{~kg} / \mathrm{m}^{2}$ in women, $<17 \mathrm{~kg} / \mathrm{m}^{2}$ in men).

The risk of malnutrition increases when the older adult does not reach a minimum of $50 \%$ of requirements for more than 3 days or when factors are influencing the dietary intake [3]. Based on research findings, up to $50 \%$ of the older persons in hospital settings are malnourished [4-6]. A recent meta-analysis from Cereda et al. (2016) demonstrates differing amounts of malnutrition across settings: community (3.1\%), outpatients $(6.0 \%)$, home-care services $(8.7 \%)$, hospital $(22.0 \%)$, nursing homes (17.5\%), long-term care (28.7\%) and rehabilitation/sub-acute care (29.4\%), based on the Mini Nutritional Assessment ${ }^{\circledR}$ [4].

The reasons why persons develop malnutrition are multifactorial (Chaps. 2, 3, and 10); consequently, a multifactorial approach is needed (Chap. 13). Malnourished persons may be grouped into those with inadequate intake, reduced uptake or bioavailability of nutrients or increased requirements caused by acute or chronic disease [7]. For example, an older adult may become malnourished because they continue adhering to a restrictive, 'healthy lifestyle' diet into their later life, despite evidence of reduced intake or absorption and increased requirements associated with co-morbid disease. We note that healthcare organisations, expert recommendations and/or individual clinicians often fail to advocate for 'stop dieting' or to evaluate restrictive diets [8].

The model Determinants of Malnutrition in Aged Persons (DoMAP) highlights these and many other major direct or indirect influencing factors of malnutrition in older adults (Fig. 4.1). The main etiologic mechanisms are placed in the middle of the model (level 1 = dark green). The factors in the light green triangle (level 


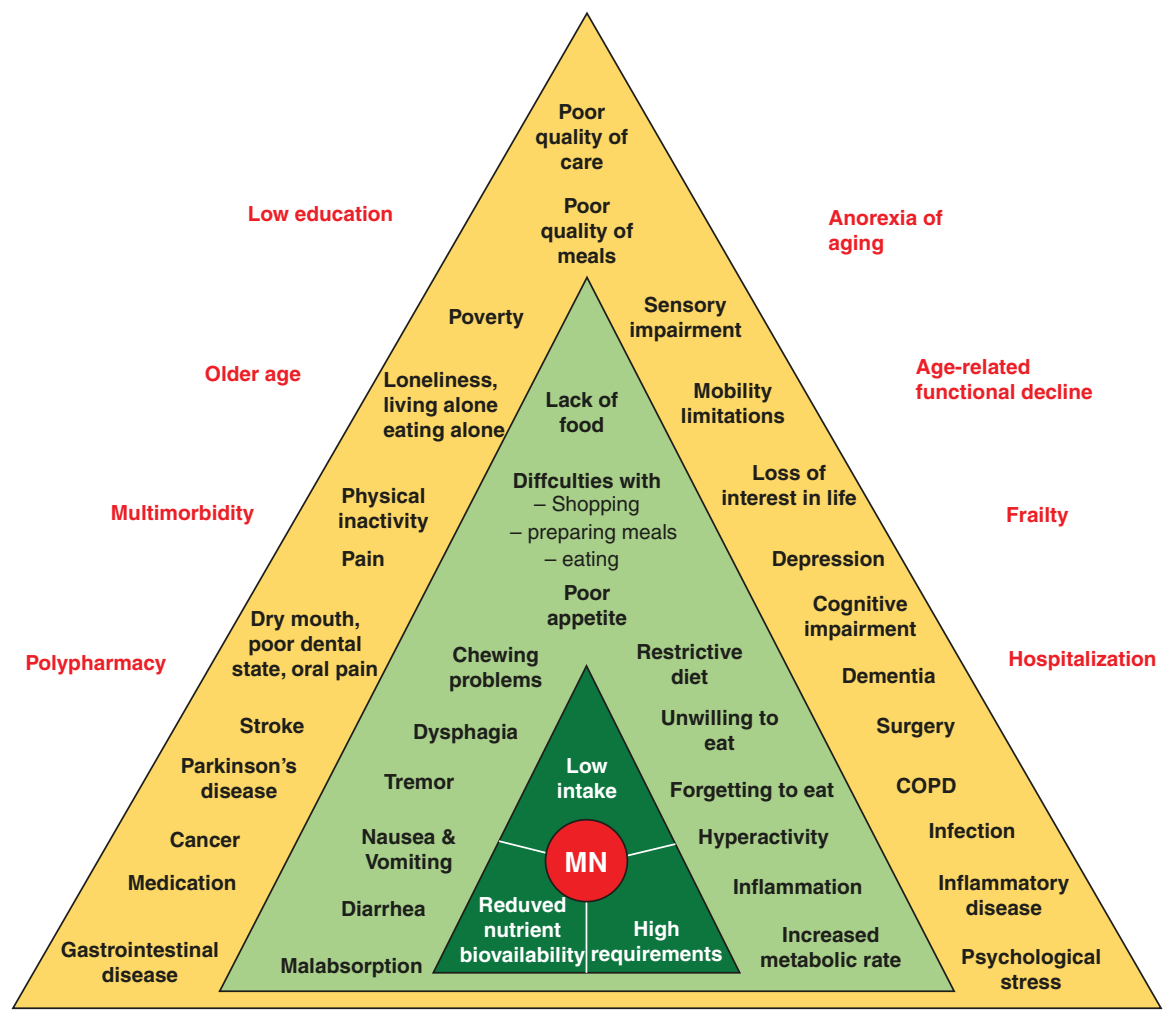

Fig. 4.1 DoMAP model: Determinants of Malnutrition in Aged Persons [9]

$2=$ lighter green) are the determinants, which directly lead to one of the main factors, for example, hyperactivity leading directly to high requirements. The third level (yellow) contains determinants, which indirectly lead to one or more central mechanisms through factors in level 2. For example, the side effect of medication may lead to poor appetite and to a lower intake. Around the pyramid are typical agerelated factors which are additionally influencing the process of malnutrition [9].

Some factors like hospitalisation or polypharmacy might be starting points of developing malnutrition. Other factors like frailty or multimorbidity may progressively worsen the nutritional status of the older adult. If the treatment of older adults with or at risk of malnutrition is individualised to identified determinants of malnutrition, outcomes are improved whether measured by functional status, quality of life or mortality [10]. A recent systematic review analysed socioeconomic factors which contribute the development of malnutrition in older adults. The authors analysed a higher risk not only for persons with a low educational level (odds ratio (OR), 1.48; 95\% (CI), 1.33-1.64; $p<0.001$ ) but also for those who live alone (OR, $1.92 ; 95 \%$ CI, 1.73-2.14; $p<0.001)$ and are single, widowed or divorced (OR, 1.73; $95 \% \mathrm{CI}, 1.57-1.90 ; p<0.001)$ and for persons with a low income level (OR, 2.69; 95\% CI, 2.35-3.08; $p<0.001)$. Therefore, nutritional care should be treated in a 
multifactorial way and must also be aware for socioeconomic aspects in the daily work regarding different types of older adults [11].

\subsection{Impact of Malnutrition on Older Adults, Healthcare Systems and the Community}

Malnutrition has major consequences on every organ system in the human body [12]. In case of a dietary inadequacy or period of fasting, the body mobilises the functional reserve to meet the requirements. This occurs across diverse parts of the body including muscles, adipose tissue and bones. A reduced muscle mass leads to a reduced muscle function, for example, a malnourished older adult with associated reduced cardiac muscle mass, which leads to a lower cardiac output. This downregulation results in a reduced renal function. Chronic malnutrition may also correspond with changes in pancreatic exocrine function, intestinal blood flow, villous architecture and intestinal permeability. This may lead to the loss of ability to reabsorb water and electrolytes within the colon. Resultant diarrhoea, with all its negative consequences, from skin irritation through to a higher mortality rate, may then occur, particularly if our example patient was severely malnourished. The immune system may also be affected leading to a higher risk of infections or delayed wound healing. An often neglected factor is the psychological consequence of malnutrition. Malnourished persons have a higher risk to develop anxiety, fear or depression. All these effects of malnutrition lead to an increased length of stay (LOS) in hospitalised patients and serious adverse consequences regarding recovery from disease, trauma and surgery [13]. However, malnutrition is not only associated with an increased risk of mortality in hospitalised older patients but also in communitydwelling older adults. All these facts have major consequences not only for individuals but also for the society [14]: in the European Union, about 20 million patients are diagnosed with diseases which are related to malnutrition. This leads to costs up to $€ 170$ billion in Europe annually $[15,16]$.

\subsection{General Nutritional Care and Prevention of Malnutrition}

Every setting and specific patient group needs an individualised and multifactorial approach to prevent malnutrition. On the European level, the European Society for Clinical Nutrition and Metabolism (ESPEN) publishes Guidelines and Consensus Papers on specific topics for specific settings that will be updated from time to time. The latest guideline, which addresses the needs of older people, was published in 2019 [4]. It is common that these guidelines have to be adapted or updated to the country-specific needs and the recommendations of the certain professional societies. For example, in Germany, the German Society for Nutritional Medicine (DGEM) and the German Network for Quality Development in Nursing have 
developed and published guidelines and standards for different settings, different health professionals and target groups [17-19].

The goal of a clinical nutrition intervention in older adults is to maintain or improve the quality of life and to ensure the intake of an appropriate amount of energy, nutrients, micronutrients and fluids [18]. In order to know how much energy is needed in older adults, knowledge about the calculation of energy intake can be helpful. The basal metabolic rate (BMR) describes the rate which a person needs to maintain the basic function of the body. In older adults, the BMR may be crudely estimated as $20 \mathrm{kcal} / \mathrm{kg}$ body weight (BW) per day. However, the daily energy expenditure depends highly on the level of physical activity (PAL), but also on age and weight of the person, and any additional requirements of acute or chronic disease, or malabsorption. The more active a person is, the more energy will be needed (Table 4.1). The PAL in older adults is usually estimated 1.2 to 1.4 [3]. Additional details on nutritional requirements are provided in Chap. 2.

Healthy nutrition should be well balanced, but specific recommendations vary widely [21]. A rudimentary approach to intake and distribution of macronutrients (carbohydrates, fat and proteins) may consider a practical guide: '50\% - 30\% $20 \%$ '. However, these values have to be understood as approximate 'ballparks' that should vary depending on individual and population-based requirements, recommendations and norms. Carbohydrates are the most important nutrient for humans in terms of quantity and providing energy for the body. In addition to supplying the body with energy and essential fatty acids, fats also serve as a component of body structures such as cell membranes or as a starting substance for other biologically active substances. Proteins play an important role in muscle growth and life itself. Proteins are made of about 20 amino acids. A lack of proteins leads to a loss of muscle strength and a higher risk of falls [22]. However, the amount varies by the nutritional status, PAL, disease and tolerance of the person [23]. The Harvard School of Public Health offers information on their website about rich, environmentalfriendly and healthy sources of proteins [24]. Many studies, reviews and recommendations suggest prioritising minimally processed plant-based protein sources (Table 4.2), eggs and lower-fat dairy and white meats (e.g. fish, poultry) over red meat and suggest limiting or avoiding processed meats.

Table 4.1 Energy consumption for various activities as measured by basal metabolic rate [20]

\begin{tabular}{|c|c|}
\hline PAL & Examples \\
\hline $1.2-1.3$ & Exclusively sedentary or lying way of life (frail, dependent, bedbound people) \\
\hline $1.4-1.5$ & $\begin{array}{l}\text { Exclusively sedentary activity with little or no strenuous leisure activity (office } \\
\text { workers, precision mechanics) }\end{array}$ \\
\hline $1.6-1.7$ & $\begin{array}{l}\text { Sitting activity, temporary additional energy expenditure for walking and standing } \\
\text { activities, little or no strenuous leisure activity (laboratory technicians, students, } \\
\text { assembly line workers) }\end{array}$ \\
\hline $1.8-1.9$ & $\begin{array}{l}\text { Mostly moving and standing work (housewives, nursing staff, waiters, mechanics, } \\
\text { craftsmen) }\end{array}$ \\
\hline $2.0-2.4$ & $\begin{array}{l}\text { Physically demanding professional work or very active leisure activities } \\
\text { (construction workers, farmers, forest workers, miners, competitive athletes) }\end{array}$ \\
\hline
\end{tabular}


Table 4.2 Categorised examples for plants rich in proteins [24]

$\begin{array}{ll}\text { Legumes } & \begin{array}{l}\text { Lentils, beans (adzuki, black, fava, chickpeas/garbanzo, kidney, lima, mung, pinto, } \\ \text { etc.), peas (green, snow, snap, split, etc.), edamame/soybeans (and products made } \\ \text { from soy: tofu, tempeh, etc.), peanuts }\end{array} \\ \begin{array}{l}\text { Nuts and } \\ \text { seeds }\end{array} & \begin{array}{l}\text { Almonds, pistachios, cashews, walnuts, hazelnuts, pecans, hemp seeds, squash and } \\ \text { pumpkin seeds, sunflower seeds, flax seeds, sesame seeds, chia seeds }\end{array} \\ \begin{array}{l}\text { Whole } \\ \text { grains }\end{array} & \text { Kamut, teff, wheat, quinoa, rice, wild rice, millet, oats, buckwheat }\end{array}$

In case that most of the proteins comes from plants, a mix of different sources should be ensured. For healthy older adults, a diet should include at least $1.0-1.2 \mathrm{~g}$ protein $/ \mathrm{kg}$ body weight/day. For certain older adults who have acute or chronic illnesses, $1.2-1.5 \mathrm{~g}$ protein/kg body weight/day may be indicated, with even higher intake for individuals with severe illness or injury [23].

In case of a renal insufficiency, the protein intake must be adapted to the stage of the disease.

Micronutrients (vitamins and minerals) cannot be produced in the body and consequently must be derived from the diet. Vitamins are involved in various important processes, such as the structure and protection of cells. For example, some vitamins play a crucial role in the formation of bones or in blood. In addition, vitamins contribute significantly to the regulation of metabolism and can also be part of enzymes. Unlike fats, carbohydrates and proteins, vitamins are not used as building blocks or as an energy source. Vitamins can be distinguished in fat-soluble (A, D, E, K) and water-soluble (C, B1, B2, B6, B12, niacin, pantothenic acid, biotin, folic acid). They can be stored differently in the body. Additional to that, there are many other minerals - such as the trace elements nickel, cobalt, copper, manganese, chromium and molybdenum and ultra-trace elements such as arsenic, lead, boron and silicon. Reference values can be found in recommendations of expert societies such as specialist societies of Germany, Austria and Switzerland (D-A-CH).

Critical nutrients and micronutrients in older age include calcium and vitamin D. Calcium and vitamin D are the most important nutrients in bone health and muscle function (Chap. 8). Vitamin D promotes protein synthesis and calcium and phosphate transport in muscles [25]. The Food and Agriculture Organization (FAO) recommended $800-1000 \mathrm{mg}$ calcium per day in men and women over 50 years [26]. The main resource of calcium is dairy but also mineral water or green vegetables, e.g. broccoli and curly kale [27]. The vitamin D intake by food is limited. The production of vitamin $\mathrm{D}$ takes place in the skin by exposing to ultraviolet $\mathrm{B}$ rays. Differences of skin colour, age, how much the skin has been exposed to the sun or the latitude in which the persons live are factors to be considered when making recommendations regarding sun exposure times [28]. In Germany, it is recommended for adults to expose their hands, face and arms to the sun for at least 5 to 15 min between 12:00 and 15:00 per day in the summertime. In winter, the time of exposure should triple. Information about the time which should be spent in the sun to produce an appropriate amount of vitamin D can be found on webpages of the country-specific professional societies. However, the production of vitamin D 
within the skin and exposure to ultraviolet B rays is limited in older adults. Therefore, vitamin D should routinely be supplemented. The recommended daily amount of vitamin $\mathrm{D}$ intake varies between the countries and populations. The International Osteoporosis Foundation (IOF) and many national recommendations recommend for seniors aged 60 years and over a supplement at a dose of 800 to $1000 \mathrm{IU} /$ day.

\subsection{The Role of Physical Activity and Training in Malnutrition Prevention}

Ageing has multiple consequences on every cell of the human body. The loss of muscle mass in older age is caused by a reduced protein synthesis [23]. Furthermore, inactivity with anabolic resistance is a contributor to develop sarcopenia [29]. Good nutrition, especially protein intake, can help slow down age-related functional decline. In combination with exercise, it is possible to maintain muscle functioning [30]. A meta-analysis of effects of progressive resistance strength training showed positive effects to improve physical functioning and improving strength and the performance of easy and complex activities on older people [31]. The ESPEN expert group recommends practical guidance for maintaining muscle health and physical function for older adults above 65 years. This includes daily physical activity for all older adults, as long as activity is possible; additionally, resistance training should be offered, when possible, as part of an overall fitness programme [23]. Additional information on physical activity, exercise and physical rehabilitation is provided in Chap. 14.

\subsection{Opportunities for Nurses and Other Healthcare Providers to Prevent Malnutrition}

The prevention and treatment of malnutrition needs a comprehensive approach by healthcare providers across the continuum of care (Chaps. 1, 6, and 13). The quality indicators in Table 4.3 highlight examples of nutritional care opportunities to prevent malnutrition in older adults. They are divided in three topics: general aspects, organisational aspects and educational aspects.

\subsection{Additionally, Good to Know}

We have included the following points of interest observed across years of providing care for older adults with malnutrition:

- Older adults with normal weight or obesity could also have undetected malnutrition [1]!

- The sarcopenia phenotype is associated with malnutrition (Chap. 8) [37].

- A potential life-threatening metabolic condition in malnourished persons after starting (mainly) parenteral feeding is the refeeding syndrome. Therefore, the 
Table 4.3 Opportunities for interdisciplinary healthcare providers to prevent malnutrition in older adults

\begin{tabular}{|c|c|}
\hline \multicolumn{2}{|l|}{ General aspects } \\
\hline $\begin{array}{l}\text { Nutrition screening and } \\
\text { assessment }\end{array}$ & $\begin{array}{l}\text { - The screening and assessment of malnutrition should be } \\
\text { embedded in admission, clinic and general practice processes } \\
\text { - Older adults screened at risk of malnutrition should receive a } \\
\text { thorough nutrition assessment within } 24-48 \mathrm{~h} \text { (Chap. 3) [10] } \\
\text { - Older persons should be monitored and considered at high risk } \\
\text { for dehydration [32] }\end{array}$ \\
\hline $\begin{array}{l}\text { High-quality, nutrient- } \\
\text { dense food choices }\end{array}$ & $\begin{array}{l}\text { - A varied diet, rich in macronutrients and micronutrients (e.g. } \\
\text { protein, calcium), should be offered regularly } \\
\text { - Food sources should provide additional energy and protein } \\
\text { when the older adult is acutely unwell, recovering from illness, } \\
\text { or malnourished [3] } \\
\text { - Older adults in hospitals, aged care settings and other facilities } \\
\text { should have the opportunity to select different diets from a } \\
\text { high-quality menu } \\
\text { - Offered food should include local produce prepared in line with } \\
\text { what older persons usually consume in everyday life [19,33] } \\
\text { - Nutrient-dense snacks and fluids should be available } 24 \text { h/day, } \\
\text { particularly in case of caring for patients with dementia } \\
\text { - In case of swallowing or chewing problems, texture-modified } \\
\text { products with an appetizing structure (i.e. moulded foods) are } \\
\text { preferred [34] }\end{array}$ \\
\hline $\begin{array}{l}\text { Limit unnecessary or } \\
\text { restrictive diets }\end{array}$ & $\begin{array}{l}\text { - Highly restrictive diets (e.g. extreme ketogenic diets, gluten-free } \\
\text { diet without medical reasons or fruitarian) should be avoided [3] } \\
\text { - Consider deprescription of weight loss or lifestyle disease diets } \\
\text { (e.g. lipid-modifying diets) in those with or at risk of } \\
\text { malnutrition } \\
\text { - Fasting periods and restrictive surgical/procedural diets should } \\
\text { be minimised, especially before/after surgery or procedures [19] }\end{array}$ \\
\hline $\begin{array}{l}\text { Consider nutritional } \\
\text { supplements }\end{array}$ & $\begin{array}{l}\text { - Oral nutritional supplements rich in energy and nutrients should } \\
\text { be offered where indicated and aligning with treatment goals [3, } \\
\text { 10] } \\
\text { - Micronutrients (e.g. vitamin D, calcium, multivitamins) should } \\
\text { be supplemented in line with local guidelines }\end{array}$ \\
\hline \multicolumn{2}{|c|}{ Organisational-related aspects } \\
\hline Assistance & $\begin{array}{l}\text { - Mealtime assistance should be offered when necessary, ensuring } \\
\text { adequate time to eat, with the goal to support self-independency } \\
{[3,19]} \\
\text { - Pre-meal toileting and mobilisation assistance, for example, to a } \\
\text { dining room or out of bed }\end{array}$ \\
\hline Environment & $\begin{array}{l}\text { The eating environment should be pleasant. An additional } \\
\text { dining room on the ward supports the social aspects of dining } \\
{[3,19]} \\
\text { - De-cluttering of meal trays and serving tables }\end{array}$ \\
\hline Mealtime interruptions & $\begin{array}{l}\text { Diagnostic procedures or medical professional visits should be } \\
\text { planned in the time between the mealtimes [19] } \\
\text { - Encourage families and friends to support food and fluid intake } \\
\text { at mealtimes }\end{array}$ \\
\hline
\end{tabular}


Table 4.3 (continued)

\begin{tabular}{|c|c|}
\hline Team care processes & $\begin{array}{l}\text { Dietician, nurses and medical professionals should have } \\
\text { scheduled meetings to support nutritional care of malnourished } \\
\text { patients (Chap. 11) [35] } \\
\text { - Clinical governance processes should be in place to support } \\
\text { nutritional care }\end{array}$ \\
\hline \multicolumn{2}{|l|}{ Educational aspects } \\
\hline Older adults and carers & $\begin{array}{l}\text { - Older adults and their relatives should get information and } \\
\text { education to prevent and treat malnutrition [19] } \\
\text { - Consumers should be included in co-designing nutrition } \\
\text { education materials }\end{array}$ \\
\hline $\begin{array}{l}\text { Interdisciplinary } \\
\text { healthcare providers }\end{array}$ & $\begin{array}{l}\text { - Staff should be well prepared to support nutritional care with } \\
\text { consideration to qualifications, skills and responsibilities [19, } \\
\text { 36] } \\
\text { - Staff should understand who to refer for ongoing supportive or } \\
\text { specialist nutritional care and how to do this } \\
\text { Nursing specialists in nutritional care should be a part of the } \\
\text { team in order to spread knowledge and to address the topic on } \\
\text { the ward [35] }\end{array}$ \\
\hline Influencers and advocates & $\begin{array}{l}\text { - Healthcare administrators, policymakers, professional bodies } \\
\text { and politicians should all be engaged to prevent malnutrition } \\
\text { Robust data and reports should be prepared and presented to } \\
\text { support prevention of malnutrition across the lifecycle and } \\
\text { continuum of care }\end{array}$ \\
\hline
\end{tabular}

start of the nutrition should be slowly 'step by step', in persons who are extremely underweight, with massive weight loss in a short time period or after prolonged starvation [2].

- Oral nutrition should be preferred wherever possible, with dedicated feeding assistance and encouragement; combination of oral and enteral or parenteral feeding is also possible [9].

- Participate on the nutrition day. It's a worldwide annual systematic collection and analysis of data in hospital wards, intensive care units and nursing homes. It can be used to demonstrate the benefits of nutritional care in a systematic, periodic way [38].

\subsection{Limits of Preventing Malnutrition}

The change of the nutritional status like losing appetite or weight can be a part of the physiological process and thus a part of ageing. On the other hand, a worsening nutritional status can influence the health status in a negative way or can also be the result of chronic or acute diseases, e.g. cancer, dementia or renal failure. In some cases, malnutrition can be an expression of a personal decision of the older adult, particularly in end-of-life situations [39]. Besides the goal to maintain or improve the weight and nutritional status of the older adult, good nutritional care should 
always consider the aspects of quality of life and what matters to the older adult. Therefore, clinical nutrition should keep in mind the ethical aspects of nutrition. Especially in end-of-life situations (Chap. 21), the following points should be considered:

- Reversible symptoms, which disturb appetite and enjoyment, like nausea, emesis, pain and chewing and swallowing problems, should be detected and treated.

- Older adults should eat the food they want to eat.

- Needs and wishes of the older adult should be followed.

- In end-stage disease, voluntary refusal to eat and drink should be discussed in the multidisciplinary team and accepted, when reversible symptoms are unable to be identified.

- To identify the older adult's will, advanced care planning could be helpful with all involved formal (and informal) caregivers.

\subsection{Implementation of Malnutrition Interventions}

The efficacy of implemented malnutrition interventions depends on different factors. A systematic review from Murimi et al. (2017) found four major factors which support the efficacy of interventions: interventions that lasted $\geq 5$ months, having $\leq 3$ focused objectives, appropriate design and use of theories [40]. To address these factors or adapt the findings in the individual organisation, an implementation plan is necessary. Implementation frameworks and theories which aim to change both patient and healthcare provider behaviour exist [41-43]; Chap. 10 is devoted to implementation approaches that support sustaining and spreading nutritional care improvements. Implementation planning should consider influencing individuals, structures and processes both within and external to the organisation [44]. An additional priority is to have sustainable financial support for the new structures and processes to support ongoing treatment provided by supportive interdisciplinary healthcare providers and nutritional care specialists. In terms of the counselling of patients, a theoretical underpinning and ongoing education of the interdisciplinary team members and specialists is required. All mentioned elements should be integrated as a part of a quality improvement system which is supported by data that is evaluated and reported regularly; this will enable continuous improvement of the nutritional care provided to older adults across healthcare settings.

\section{Take-Home Points}

Many hospitals and nursing homes globally are already working with guidelines or expert standards. However, this does not mean that a good nutritional care is implemented in the daily practice $[45,46]$. To self-assess application of learning to practice, the following practical questions should be answered:

- Is the offered food made in a way you (or your grandparents) would enjoy?

- Is the whole care process focused on the needs and wishes of the older adults/ residents? 
- Do you know the macronutrients and micronutrients?

- Do you screen and assess all older adults/residents for malnutrition risk regularly?

- Do you know who is responsible in the nutritional process of your organisation?

- Is the nutritional process standardised and implemented in a quality improvement system of your organisation?

\section{References}

1. Cederholm T, Bosaeus I, Barazzoni R, Bauer J, van Gossum A, Klek S et al (2015) Diagnostic criteria for malnutrition - an ESPEN consensus statement. Clin Nutr 34:335-340. https://doi. org/10.1016/j.clnu.2015.03.001

2. Cederholm T, Barazzoni R, Austin P, Ballmer P, Biolo G, Bischoff SC et al (2017) ESPEN guidelines on definitions and terminology of clinical nutrition. Clin Nutr 36:49-64. https://doi. org/10.1016/j.clnu.2016.09.004

3. Volkert D, Beck AM, Cederholm T, Cruz-Jentoft A, Goisser S, Hooper L et al (2019) ESPEN guideline on clinical nutrition and hydration in geriatrics. Clin Nutr 38:10-47. https://doi. org/10.1016/j.clnu.2018.05.024

4. Cereda E, Pedrolli C, Klersy C, Bonardi C, Quarleri L, Cappello S et al (2016) Nutritional status in older persons according to healthcare setting: a systematic review and metaanalysis of prevalence data using MNA®. Clin Nutr 35:1282-1290. https://doi.org/10.1016/j. clnu.2016.03.008

5. Cereda E, Veronese N, Caccialanza R (2018) The final word on nutritional screening and assessment in older persons. Curr Opin Clin Nutr Metab Care 21:24-29. https://doi.org/10.1097/ MCO.0000000000000431

6. Lacau St Guily J, Bouvard É, Raynard B, Goldwasser F, Maget B, Prevost A et al (2018) NutriCancer: a French observational multicentre cross-sectional study of malnutrition in elderly patients with cancer. J Geriatr Oncol 9:74-80. https://doi.org/10.1016/j.jgo.2017.08.003

7. Agarwal E, Miller M, Yaxley A, Isenring E (2013) Malnutrition in the elderly: a narrative review. Maturitas 76:296-302. https://doi.org/10.1016/j.maturitas.2013.07.013

8. Lee RJ, Collins PF, Elmas K, Bell JJ (2021) Restrictive diets in older malnourished cardiac inpatients: a cross-sectional study. Nutr Diet 78:121-127. https://doi.org/10.1111/1747-0080.12590

9. Volkert D, Kiesswetter E, Cederholm T, Donini LM, Eglseer D, Norman K et al (2019) Development of a model on determinants of malnutrition in aged persons: a MaNuEL project. GGM 5:1-8. https://doi.org/10.1177/2333721419858438

10. Schuetz P, Fehr R, Baechli V, Geiser M, Deiss M, Gomes F et al (2019) Individualised nutritional support in medical inpatients at nutritional risk: a randomised clinical trial. Lancet 393:2312-2321. https://doi.org/10.1016/S0140-6736(18)32776-4

11. Besora-Moreno M, Llauradó E, Tarro L, Solà R (2020) Social and economic factors and malnutrition or the risk of malnutrition in the elderly: a systematic review and meta-analysis of observational studies. Nutrients 12:737. https://doi.org/10.3390/nu12030737

12. Saunders J, Smith T (2010) Malnutrition: causes and consequences. Clin Med (Lond) 10:624-627. https://doi.org/10.7861/clinmedicine.10-6-624

13. Norman K, Pichard C, Lochs H, Pirlich M (2008) Prognostic impact of disease-related malnutrition. Clin Nutr 27:5-15. https://doi.org/10.1016/j.clnu.2007.10.007

14. Sanchez-Rodriguez D, Locquet $M$, Reginster J-Y, Cavalier E, Bruyère $O$, Beaudart C (2020) Mortality in malnourished older adults diagnosed by ESPEN and GLIM criteria in the SarcoPhAge study. J Cachexia Sarcopenia Muscle 11(5):1200-1211. https://doi.org/10.1002/ jcsm. 12574

15. Freijer K, Tan SS, Koopmanschap MA, Meijers JMM, Halfens RJG, Nuijten MJC (2013) The economic costs of disease related malnutrition. Clin Nutr 32:136-141. https://doi. org/10.1016/j.clnu.2012.06.009 
16. Arribalzaga EB (2009) Valoración de la circunferencia de la pantorrilla Como indicador de riesgo de desnutrición en personas mayores [valuation of the circumference of the calf like indicator of risk of malnutrition in senior persons]. Nutr Hosp 24:368-369

17. Valentini L, Volkert D, Schütz T, Ockenga J, Pirlich M, Druml W et al (2013) Leitlinie der Deutschen Gesellschaft für Ernährungsmedizin (DGEM): DGEM-Terminologie in der Klinischen Ernährung. Aktuel Ernahrungsmed 38:97-111. https://doi. org/10.1055/s-0032-1332980

18. Volkert D, Bauer M, Frühwald T, Gehrke I, Lechleitner M, Lenzen-Großimlinghaus R et al (2013) Klinische Ernährung in der Geriatrie: Leitlinie der Deutschen Gesellschaft für Ernährungsmedizin (DGEM) in Zusammenarbeit mit der GESKES, der AKE und der DGG. Akt Ernähr Med 38:e1-e48. https://doi.org/10.1055/s-0033-1343169

19. DNQP (2017) Expertenstandard Ernährungsmanagement zur Sicherung und Förderung der oralen Ernährung in der Pflege, 1st edn. Hochschule Osnabrück, Osnabrück

20. Mathias D (2018) Physical activity level. In: Mathias D (ed) Fit und gesund von 1 bis Hundert. Springer, Berlin, p 15. https://doi.org/10.1007/978-3-662-56307-6_11

21. Venn BJ (2020) Macronutrients and human health for the 21st century. Nutrients 12:2363. https://doi.org/10.3390/nu12082363

22. Rizzoli R, Bonjour J-P (2004) Dietary protein and bone health. J Bone Miner Res 19:527-531. https://doi.org/10.1359/JBMR.040204

23. Deutz NEP, Bauer JM, Barazzoni R, Biolo G, Boirie Y, Bosy-Westphal A et al (2014) Protein intake and exercise for optimal muscle function with aging: recommendations from the ESPEN expert group. Clin Nutr 33:929-936. https://doi.org/10.1016/j.clnu.2014.04.007

24. Harvard School of Public Health (2021) The nutrition source. Protein. http://www.hsph.harvard.edu/nutritionsource/what-should-you-eat/protein/. Accessed 2 Apr 2021

25. Morelli S, de Boland AR, Boland RL (1993) Generation of inositol phosphates, diacylglycerol and calcium fluxes in myoblasts treated with 1,25-dihydroxyvitamin D3. Biochem J 289(Pt 3):675-679. https://doi.org/10.1042/bj2890675

26. FAO (2001) Human vitamin and mineral requirements: report of a joint FAO/WHO expert consultation Bangkok, Thailand. http://www.fao.org/3/a-y2809e.pdf. Accessed 3 Nov 2020

27. IOF (2020) Calcium content of common foods. https://www.osteoporosis.foundation/patients/ prevention/calcium-content-of-common-foods. Accessed 3 Nov 2020

28. Wacker M, Holick MF (2013) Sunlight and vitamin D: a global perspective for health. Dermatoendocrinology 5:51-108. https://doi.org/10.4161/derm.24494

29. Dickinson JM, Volpi E, Rasmussen BB (2013) Exercise and nutrition to target protein synthesis impairments in aging skeletal muscle. Exerc Sport Sci Rev 41:216-223. https://doi. org/10.1097/JES.0b013e3182a4e699

30. Boirie Y (2009) Physiopathological mechanism of sarcopenia. J Nutr Health Aging 13:717-723. https://doi.org/10.1007/s12603-009-0203-x

31. Liu C-J, Latham NK (2009) Progressive resistance strength training for improving physical function in older adults. Cochrane Database Syst Rev 2009:CD002759. https://doi. org/10.1002/14651858.CD002759.pub2

32. Hooper L, Bunn D, Jimoh FO, Fairweather-Tait SJ (2014) Water-loss dehydration and aging. Mech Ageing Dev 136-137:50-58. https://doi.org/10.1016/j.mad.2013.11.009

33. Hauner H, Beyer-Reiners E, Bischoff G, Breidenassel C, Ferschke M, Gebhardt A et al (2019) Leitfaden Ernährungstherapie in Klinik und Praxis (LEKuP). Aktuel Ernahrungsmed 44:384-419. https://doi.org/10.1055/a-1030-5207

34. Farrer O, Olsen C, Mousley K, Teo E (2016) Does presentation of smooth pureed meals improve patients consumption in an acute care setting: a pilot study. Nutr Diet 73:405-409. https://doi.org/10.1111/1747-0080.12198

35. Reber E, Strahm R, Bally L, Schuetz P, Stanga Z (2019) Efficacy and efficiency of nutritional support teams. J Clin Med 8(9):1281. https://doi.org/10.3390/jcm8091281

36. Volkert D, Chourdakis M, Faxen-Irving G, Frühwald T, Landi F, Suominen MH et al (2015) ESPEN guidelines on nutrition in dementia. Clin Nutr 34:1052-1073. https://doi.org/10.1016/j. clnu.2015.09.004 
37. Cruz-Jentoft AJ, Bahat G, Bauer J, Boirie Y, Bruyère O, Cederholm T et al (2019) Sarcopenia: revised European consensus on definition and diagnosis. Age Ageing 48:16-31. https://doi. org/10.1093/ageing/afy 169

38. Schindler K, Pichard C, Sulz I, Volkert D, Streicher M, Singer P et al (2017) nutritionDay: 10 years of growth. Clin Nutr 36:1207-1214. https://doi.org/10.1016/j.clnu.2016.11.004

39. Felder S, Lechtenboehmer C, Bally M, Fehr R, Deiss M, Faessler L et al (2015) Association of nutritional risk and adverse medical outcomes across different medical inpatient populations. Nutrition 31:1385-1393. https://doi.org/10.1016/j.nut.2015.06.007

40. Murimi MW, Kanyi M, Mupfudze T, Amin MR, Mbogori T, Aldubayan K (2017) Factors influencing efficacy of nutrition education interventions: a systematic review. J Nutr Educ Behav 49:142-165.e1. https://doi.org/10.1016/j.jneb.2016.09.003

41. Nilsen P (2015) Making sense of implementation theories, models and frameworks. Implement Sci 10:53. https://doi.org/10.1186/s13012-015-0242-0

42. Kwasnicka D, Dombrowski SU, White M, Sniehotta F (2016) Theoretical explanations for maintenance of behaviour change: a systematic review of behaviour theories. Health Psychol Rev 10:277-296. https://doi.org/10.1080/17437199.2016.1151372

43. Bluethmann SM, Bartholomew LK, Murphy CC, Vernon SW (2017) Use of theory in behavior change interventions. Health Educ Behav 44:245-253. https://doi. org/10.1177/1090198116647712

44. Laur C, Valaitis R, Bell J, Keller H (2017) Changing nutrition care practices in hospital: a thematic analysis of hospital staff perspectives. BMC Health Serv Res 17:498. https://doi. org/10.1186/s12913-017-2409-7

45. Fleischer N, Klewer J (2011) Untersuchung des Ernährungsmanagements vor und während der Implementierung des nationalen Expertenstandards Ernährungsmanagement zur Sicherstellung und Förderung der oralen Ernährung in der Pflege in einer stationären Altenpflegeeinrichtung. HBScience 2:143-149. https://doi.org/10.1007/s16024-011-0037-4

46. Volkert D, Weber J, Kiesswetter E, Sulz I, Hiesmayr M (2019) Nutritional situation in German hospitals-results of the nutritionDay project 2018. Ernährungs Umschau 66:204-211. https:// doi.org/10.4455/eu.2019.045

\section{Recommended Reading}

Bell JJ, Geirsdóttir ÓG, Hertz K, Santy-Tomlinson J, Skúladóttir SS, Eleuteri S, Johansen A (2021) Orthogeriatrics: the management of older patients with fragility fractures. In: Nutritional care of the older patient with fragility fracture: opportunities for systematised, interdisciplinary approaches across acute care, rehabilitation and secondary prevention settings. $\mathrm{Hg}$. v. Paolo Falaschi und David Marsh, Cham

ten Cate D, Ettema RGA, Waal H-d, Getty, Bell JJ, Verbrugge R, Schoonhoven L, Schuurmans MJ (2020) Interventions to prevent and treat malnutrition in older adults to be carried out by nurses: a systematic review. J Clin Nurs 29(11-12):1883-1902. https://doi.org/10.1111/ jocn. 15153

Druml C, Ballmer PE, Druml W, Oehmichen F, Shenkin A, Singer P et al (2016) ESPEN guideline on ethical aspects of artificial nutrition and hydration. Clin Nutr 35(3):545-556. https://doi. org/10.1016/j.clnu.2016.02.006

Keller HH, Carrier N, Slaughter SE, Lengyel C, Steele CM, Duizer L et al (2017) Prevalence and determinants of poor food intake of residents living in long-term care. J Am Med Dir Assoc 18(11):941-947. https://doi.org/10.1016/j.jamda.2017.05.003

O'Keeffe M, Kelly M, O'Herlihy E et al (2019) Potentially modifiable determinants of malnutrition in older adults. A systematic review. Clin Nutr 38(6):2477-2498. https://doi.org/10.1016/j. clnu.2018.12.007

Schuetz P, Fehr R, Baechli V, Geiser M, Deiss M, Gomes F, Kutz A, Tribolet P, Bregenzer T, Braun N, Hoess C, Pavlicek V, Schmid S, Bilz S, Sigrist S, Brändle M, Benz C, Henzen C, Mattmann S, Thomann R, Brand C, Rutishauser J, Aujesky D, Rodondi N, Donzé J, Stanga Z, Mueller B 
(2019) Individualised nutritional support in medical inpatients at nutritional risk. A randomised clinical trial. Lancet 393(10188):2312-2321. https://doi.org/10.1016/S0140-6736(18)32776-4

Visser M, Volkert D, Corish C, Geisler C, de Groot LC, Cruz-Jentoft AJ et al (2017) Tackling the increasing problem of malnutrition in older persons. The malnutrition in the elderly (MaNuEL) knowledge hub. Nutr Bull 42(2):178-186. https://doi.org/10.1111/nbu.12268

Volkert D, Beck AM, Cederholm T, Cereda E, Cruz-Jentoft A, Goisser S et al (2019) Management of malnutrition in older patients-current approaches, evidence and open questions. J Clin Med 8(7). https://doi.org/10.3390/jcm8070974

\section{Training Courses (Selection)}

Germany: Training in nutritional medicine for nursing and assistants. https://www.dgem.de/ pflege-und-assistenzpersonal

UK: Nursing careers resource. https://www.ren.org.uk/professional-development/nursing-careersresource

UK: The British nutrition foundation. https://www.nutrition.org.uk/nutritionscience/life/olderadults.html

Open Access This chapter is licensed under the terms of the Creative Commons Attribution 4.0 International License (http://creativecommons.org/licenses/by/4.0/), which permits use, sharing, adaptation, distribution and reproduction in any medium or format, as long as you give appropriate credit to the original author(s) and the source, provide a link to the Creative Commons license and indicate if changes were made.

The images or other third party material in this chapter are included in the chapter's Creative Commons license, unless indicated otherwise in a credit line to the material. If material is not included in the chapter's Creative Commons license and your intended use is not permitted by statutory regulation or exceeds the permitted use, you will need to obtain permission directly from the copyright holder. 